\title{
Clypeina helvetica Morellet and Morellet, 1918, revisited. A Priabonian (Late Eocene) dasycladalean alga from the Diablerets Nappe of the Helvetic Alps, southwestern Switzerland
}

\author{
Felix Schlagintweit • Telm Bover-Arnal • \\ Ursula Menkveld-Gfeller • André Strasser
}

\begin{abstract}
The dasycladale Clypeina helvetica was described and illustrated with six drawings by Morellet and Morellet (Bull Soc Géol Fr $4^{\circ}$ ser 18:102-105, 1918) from the "Bartonian" of the Helvetic Zone of southwestern Switzerland. Since then, $C$. helvetica has not been reported again neither from Switzerland nor from any other locality. Abundant material sampled from the Priabonian Diablerets Member of the Sanetsch Formation in the type area Lapis de Tsanfleuron permits a more detailed description of the species including biometric data and thin-section illustrations. $C$. helvetica is validated by the designation of a lectotype to serve as nomenclatural type.
\end{abstract}

Keywords Dasycladales · Eocene - Taxonomy · Helvetic Alps · Switzerland

\section{Introduction}

In 1918, Lucien and Jean Morellet described a new species of dasycladalean green alga in an Eocene fragment of rock from Lapis (Lapies) de Tsanfleuron (Diablerets Nappe, western Swiss Alps). The rock belongs to the fossiliferous beds traditionally known as "Couches à Cérithes" and is

F. Schlagintweit $(\bowtie)$

Lerchenauerstr. 167, 80935 Munich, Germany

e-mail: ef.schlagintweit@t-online.de

T. Bover-Arnal · A. Strasser

Département de Géosciences, Université de Fribourg,

Chemin du Musée 6, 1700 Fribourg, Switzerland

U. Menkveld-Gfeller

Naturhistorisches Museum der Burgergemeinde Bern,

Bernastr. 15, 3005 Bern, Switzerland characterized by a floatstone texture with the presence of abundant verticils of this dasycladalean alga and shells of potamidid gastropods. They named this alga Clypeina helvetica.

Since then, almost 100 years have passed and $C$. helvetica still is known only from its type locality and original description, which includes an illustration with six drawings (Morellet and Morellet 1918) (Fig. 1). For this reason, Deloffre and Génot (1982) stated that C. helvetica is "relatively unknown", "poorly quoted and illustrated", and that "the validity of this species is dubious". Based on material collected at the type locality for the study of its Late Eocene transgressive rocks (Bover-Arnal et al. 2011), the present paper aims to amend these deficiencies by providing a detailed description of $C$. helvetica, including biometric data and photographic illustrations, as well as to formalize the species validity.

According to the available bibliography, dasycladales suffered a drastic reduction of species diversity during the Eocene after a peak in the Late Paleocene with 105 species in the Thanetian (Barattolo 2002). From 52 species in the Early Eocene (Ypresian) the number became reduced to only eight species in the Priabonian (Barattolo 2002). Therefore, this study is of significance in that it provides a data set of a poorly known species, which flourished in a time period characterized by a reduced Dasycladaceae taxonomic diversity.

\section{Geological setting}

The Tsanfleuron-Sanetsch area in southwestern Switzerland (Fig. 2) is part of the Alpine Helvetic zone and is composed of a nappe pile that consists of Mesozoic and Paleogene rocks. Lower Cretaceous karstified limestones 
a

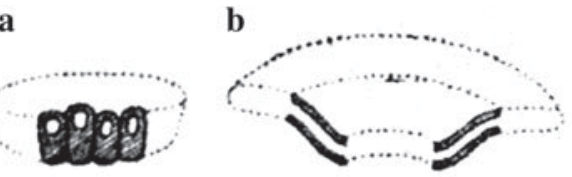

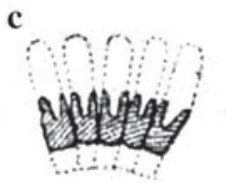

$1 \mathrm{~mm}$
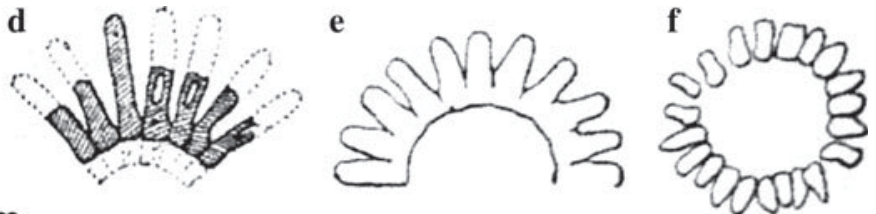

Fig. 1 Original drawings (a-f) of Clypeina helvetica by Morellet and Morellet (1918, fig. 2)

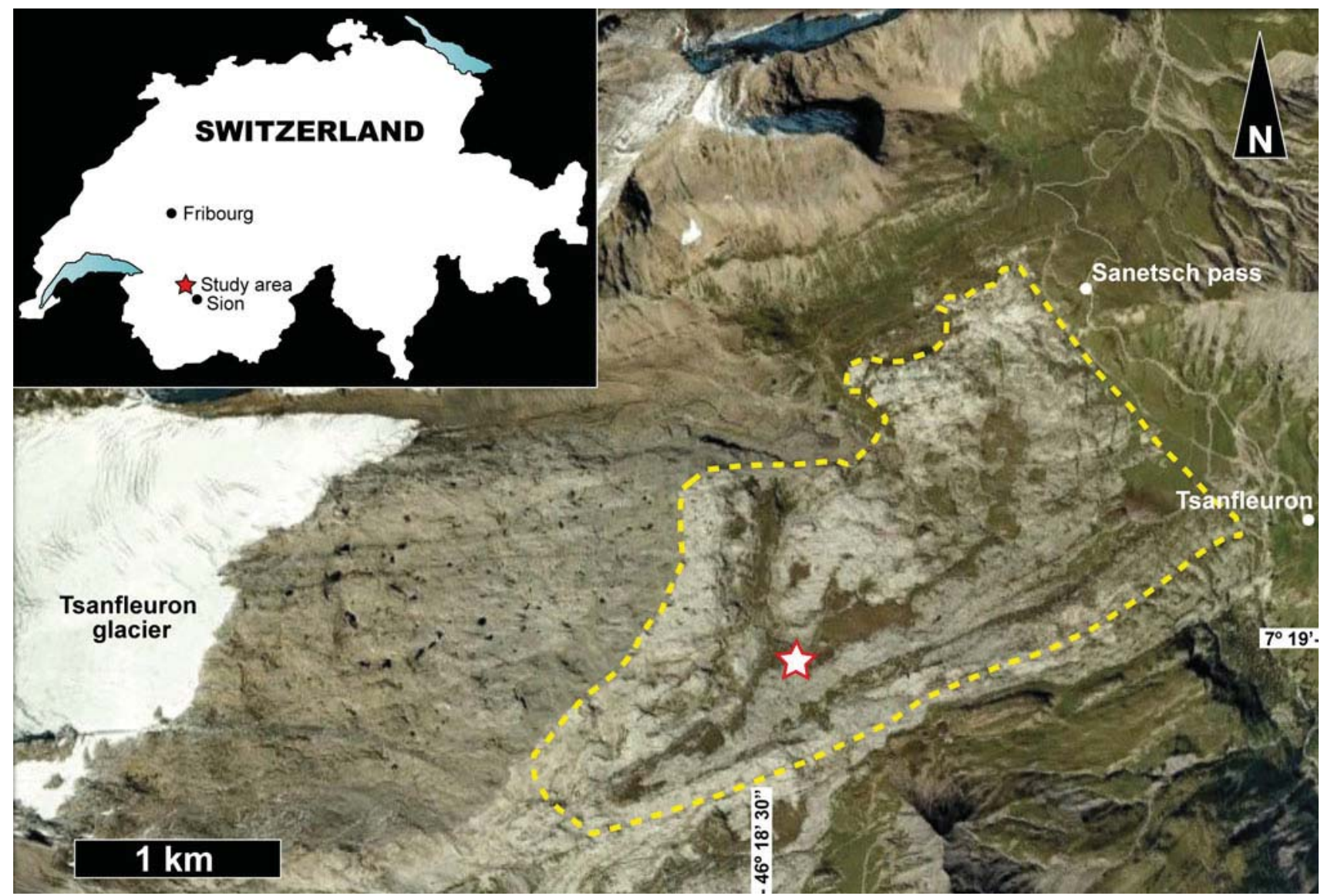

Fig. 2 Area where the Diablerets Mb. (Early Priabonian; Sanetsch Fm.), which contains the levels with prolific Clypeina helvetica, crops out (dashed yellow line). The star indicates the position of the logged section illustrated in Fig. 4

of the Schrattenkalk Formation are overlain by transgressive Paleogene (Eocene to Oligocene) strata. The transgressive rocks comprise (roughly summarized from base to top): lacustrine, brackish, and shallow-marine limestones with marly interbeds, cross-bedded sandstones, limestones with nummulitids, marls with Globigerina, and flysch deposits (Menkveld-Gfeller 1994). The informal "Couches à Cerithes" of the type area are today assigned to the Diablerets Member of the Sanetsch Formation. Based on the nummulites occurring in the overlying strata, the Diablerets Member is Early Priabonian in age (Menkveld-Gfeller 1994). Dasycladalean algae, including the dispersed verticillar disks of $C$. helvetica, are common constituents in the terrigenous-influenced, partly brackish limestones of the Diablerets Member resting upon a karstified paleorelief of the Schrattenkalk Formation (Bover-Arnal et al. 2011) (Figs. 3, 4).

\section{Systematic paleontology}

Division Chlorophyta Reichenbach, 1834

Order Dasycladales Pascher, 1931

Family Acetabulariaceae (Endlicher) Hauck, 1885

Tribus Clypeineae Elliott, 1968

Genus Clypeina (Michelin) Bassoullet et al. 1978

Clypeina helvetica Morellet and Morellet, 1918

Figs. 5, 6, 7, 8 


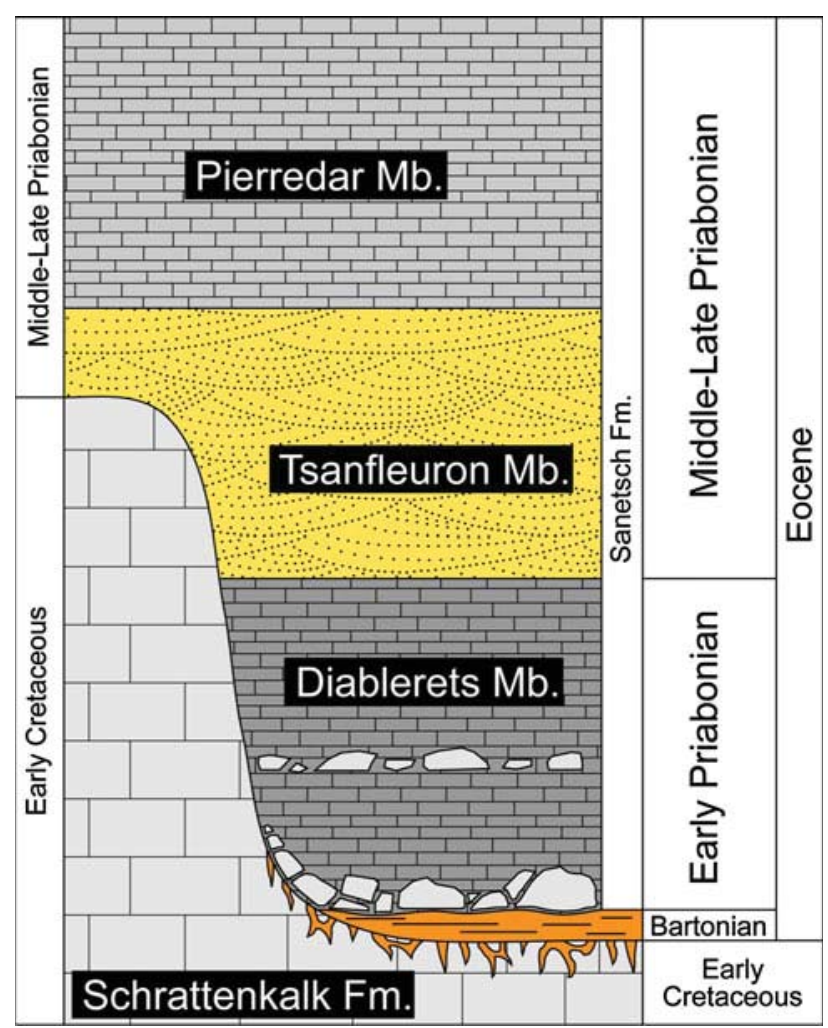

Fig. 3 Stratigraphy of Cretaceous to Eocene rocks at the Lapis de Tsanfleuron. Modified from Bover-Arnal et al. (2011). The ages of the deposits are taken from Herb (1988), Weidmann et al. (1991), Menkveld-Gfeller (1993, 1994, 1995), and Linder (2005)

*1918 Clypeina helvetica $\mathrm{n}$. sp.--Morellet and Morellet: 105, fig. 2a-f

Lectotype versus holotype

Morellet and Morellet (1918) did not designate a holotype. Their description was based on a rock sample provided by Maurice Lugeon indicated as no. 11289 deposited at the Geological Museum in Lausanne (Switzerland). The sample is still stored in the collection of the museum and is illustrated in Fig. 5a, b. From this rock sample full of algal debris, the authors made six drawings, stating that the color contrast between the algal remains and the host rock is too small for providing good-quality photographs. From the original drawings, the transverse view illustrated as Fig. 2F in Morellet and Morellet (1918) and refigured here in Fig. 1f is designated as a lectotype (articles 9.10, 9.11 I.C.B.N.; McNeill et al. 2006).

Type locality

The rock sample on which the description of $C$. helvetica is based was collected from the "Couches à Cérithes des lapiez de Zanfleuron” (Morellet and Morellet 1918). These

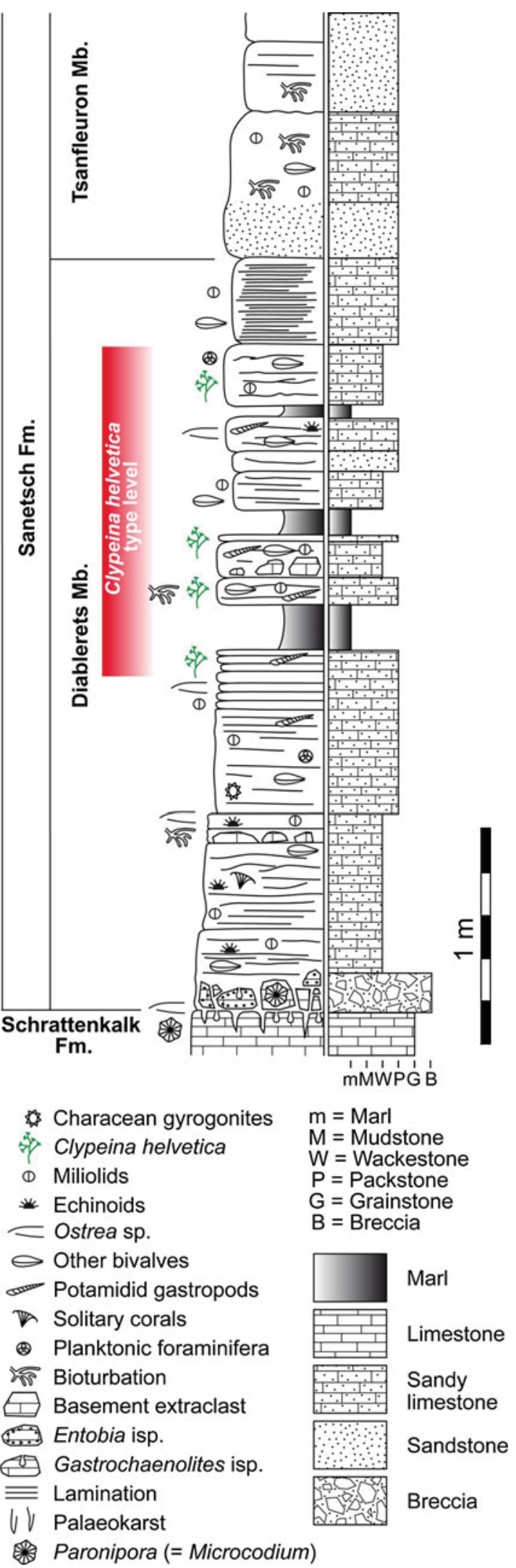

Fig. 4 Log of the Diablerets Member showing the lithostratigraphic context for the type material of Clypeina helvetica (see Fig. 2 for position of the $\log$ ) 

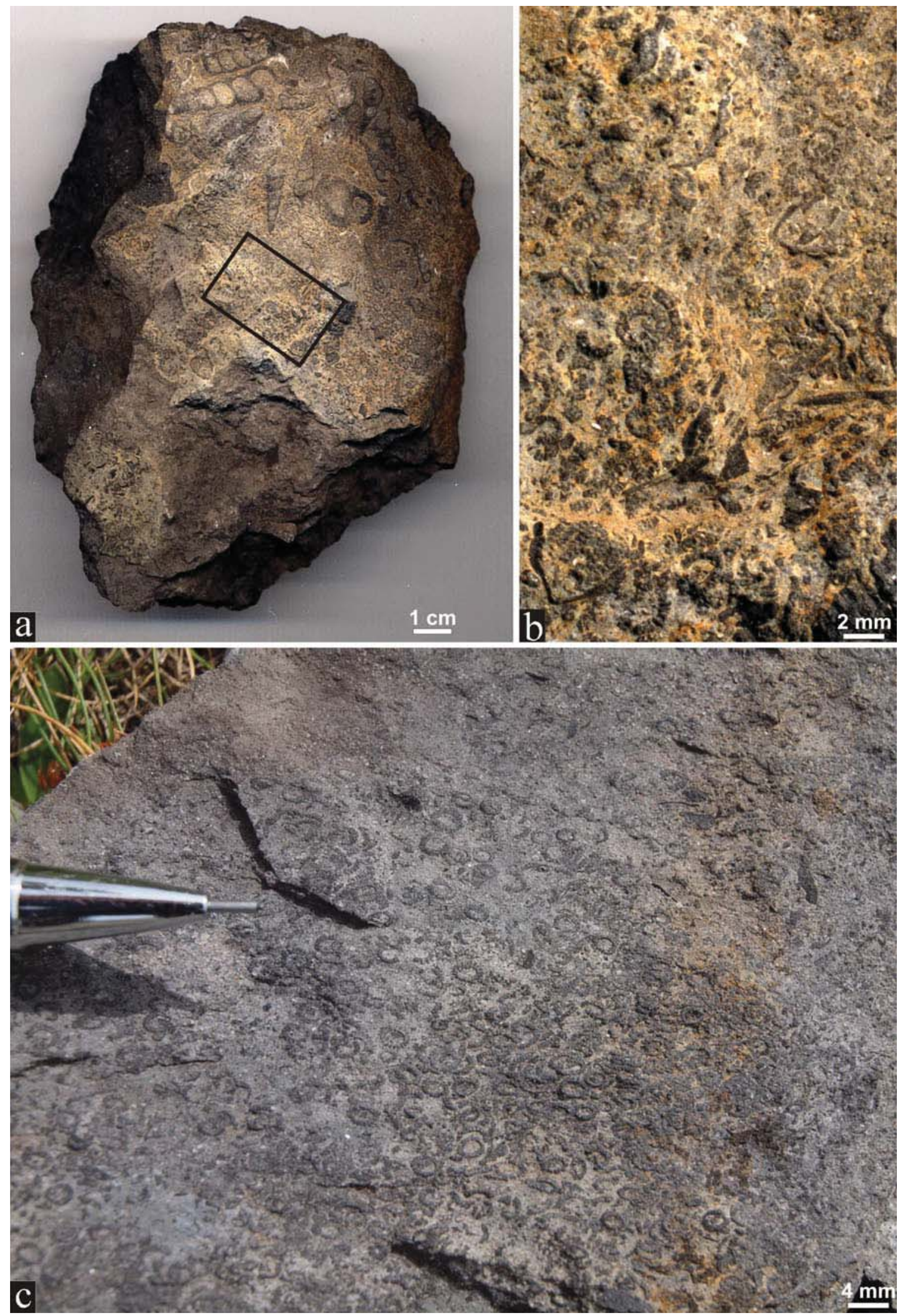
Fig. 5 Clypeina helvetica Morellet and Morellet. a Rock sample (collected by M. Lugeon in 1906) from the Lapis de Tsanfleuron area, on which the original description and drawings of Morellet and Morellet (1918) were based. Note that this sample was described as "totally intermingled with Clypeina debris" (Morellet and Morellet 1918, p. 105: "absolument pétri de debris d'un Clypeina"). The black rectangle marks the detailed view shown in b. Sample no. 11289 , Musée Géologique Lausanne, Couches à Cérithes (=Diablerets Member of Menkveld-Gfeller 1994). b Detail from a showing the dispersed verticils of Clypeina helvetica. c Rock surface with abundant dispersed whorls of Clypeina helvetica (from Bover-Arna et al. 2011, fig. 13c). Diablerets Member, Lapis de Tsanfleuron, Early Priabonian

are the only data available about the type locality. The location certainly corresponds to the Lower Priabonian succession of the Sanetsch Formation, from the Lapis de Tsanfleuron that has been described by Weidmann et al. (1991), Menkveld-Gfeller (1993, 1994), and Bover-Arnal et al. (2011). This succession crops out in an area of $\sim 12 \mathrm{~km}^{2}$ (Fig. 2), where Clypeina helvetica occurs with potamidid gastropods and pelecypods in sandy marly limestones (Figs. 3, 4; see also Fig. 6 in Menkveld-Gfeller 1994). The Priabonian outcrops of the Lapis de Tsanfleuron are situated within a small valley running in a SW direction, (Coordinates: $46^{\circ} 18^{\prime} \mathrm{N} / 7^{\circ} 16^{\prime} \mathrm{E}$, sheet No. 1286 , St-Léonard, 1:25,000, Swisstopo).

Type level

Light-brown to dark grey wacke- to floatstones containing siliciclastic material (Fig. 6). Shells of tiny ostracodes and miliolids are the dominating microfauna. Besides Clypeina helvetica, potamidid gastropods and cardiid bivalves constitute the dominant macrobiota. Also present are rare and fine debris of corallinacean algae, remains of crustaceans, individual tests of the larger miliolid Orbitolites sp. (Fig. 6b) and lithoclasts from the Lower Cretaceous Schrattenkalk Formation, which contain Paronipora (Microcodium) within fissures. From the studied thin-sections, the following trend was observed: the more gastropod shells the less Clypeina remains, with the two end-members of pure gastropod or pure Clypeina limestones.

\section{Material}

The thin-sections of this study are housed at the Naturhistorisches Museum of the Burgergemeinde Bern, section Earth Sciences, material Ursula Menkveld-Gfeller (numbers: SP 139, 139-1, 139 D-2), and material Telm Bover-Arnal (LT 03).

\section{Diagnosis}

In the original description, no diagnosis was given. It is provided here as follows: Large-sized Clypeina (diameter
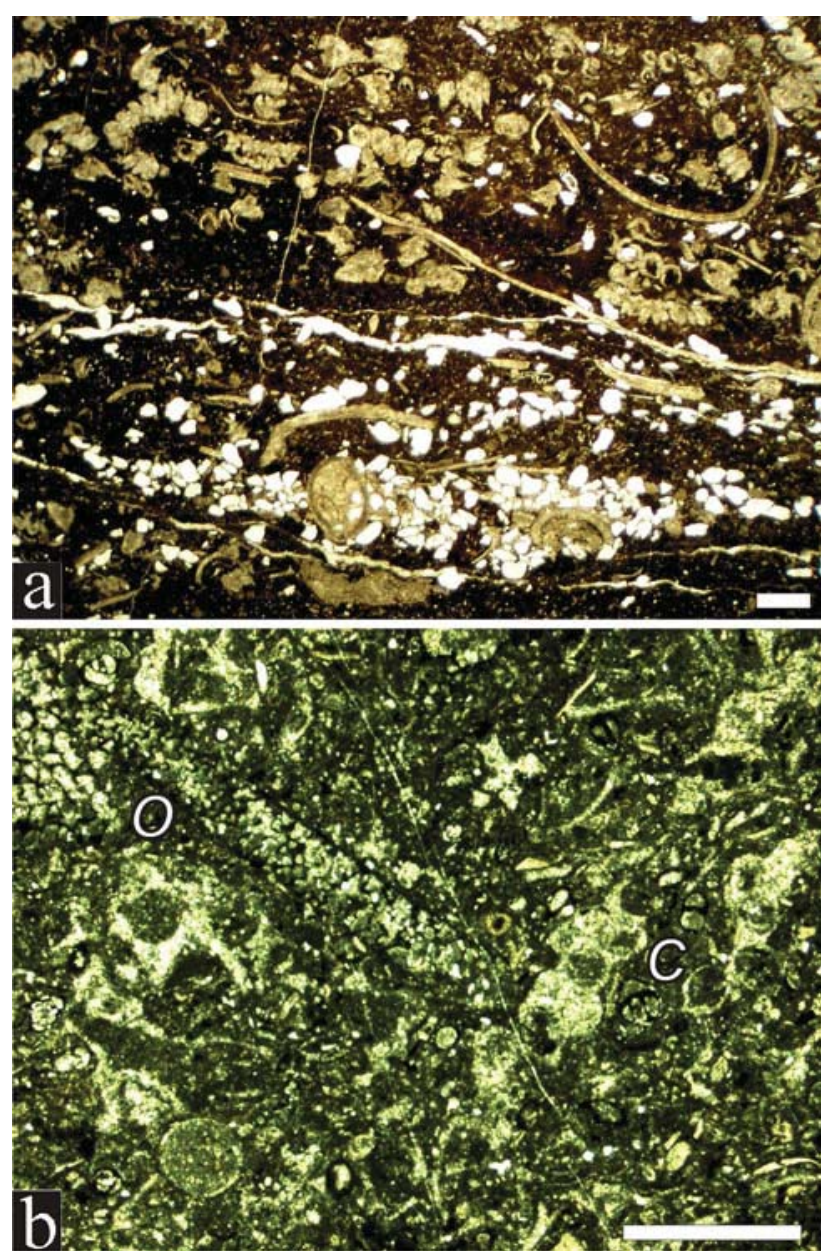

Fig. 6 Microfacies. a Wackestone with quartz grains arranged in layers (lower part of the photograph), scattered pelecypod shells and abundant remains of Clypeina helvetica Morellet and Morellet (upper part). Thin-section SP 139 D-2. b Wackestone with debris of Clypeina helvetica Morellet and Morellet $(C)$, and miliolids including a large test of Orbitolites sp. $(O)$. Thin-section LT 03. Diablerets Member, Lapis de Tsanfleuron, Early Priabonian. Scale bars $1 \mathrm{~mm}$

up to $2.63 \mathrm{~mm}$ ) only known as isolated shallow saucershaped articles (whorls) consisting of numerous (up to 32) laterals. The laterals are fused only at their proximal parts (max. 1/4 of their length), thus giving to the whorl an outline that resembles a flower. The distal ends of the pores are not calcified and were presumably open. The original individual sheath calcification comprises a thin outer microcrystalline and a thick inner layer consisting of yellowish, radial-fibrous calcite. Whorls may also be recrystallized to light sparry calcite.

Description Rather large Clypeina species (D: up to $2.63 \mathrm{~mm}$ ) being preserved only as scattered individual whorls (Fig. 5c). Two or more successive whorls were not observed as obviously the stipe was only poorly calcified. The whorls are saucer-shaped and exhibit a short portion arranged perpendicular to slightly inclined to the main stem then bending upwards before again bending slightly 

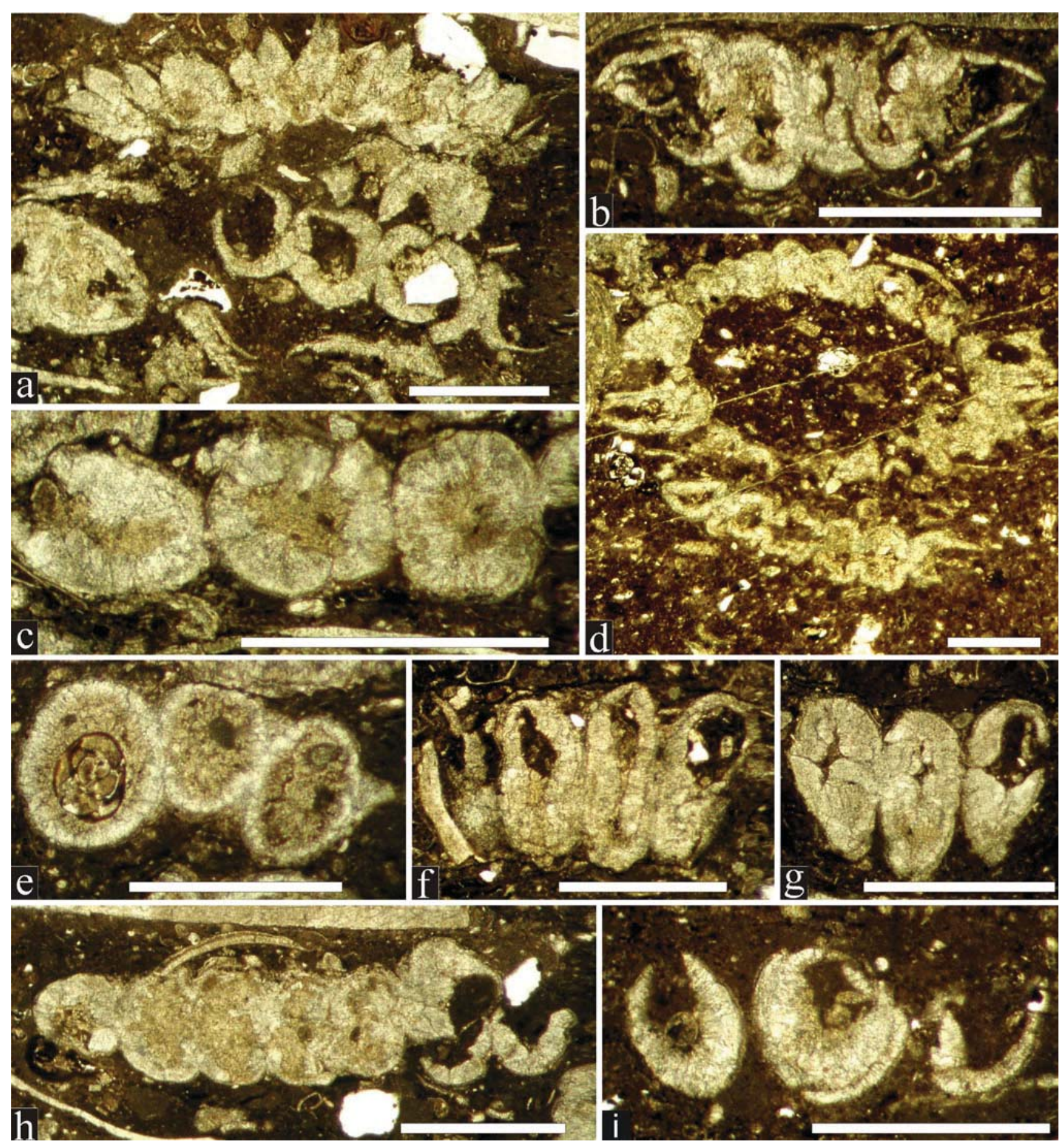

Fig. 7 Clypeina helvetica Morellet and Morellet exhibiting radialfibrous calcitic preservation. a Oblique (above) and tangential section (below). b Deep longitudinal-tangential section of a comparably small specimen. c, e, i Tangential sections of three laterals loose $(\mathbf{c}, \mathbf{e})$ or without contact (i) to each other. Note the occupation of the original pore space by cement encapsuling bioclasts (miliolid foraminifer in $\mathbf{e}$ ).

backwards in a plane forming the shape of a shallow saucer (Fig. 1b). The numerous primary laterals (w: 21-32) are only fused at their base and then become individualized during growth, giving the whorl a flower-shaped outline in d Oblique transverse section. $\mathbf{f}-\mathbf{g}$ Tangential sections cutting the inclined portion of the whorl with the pores in the upper part h Tangential section. Diablerets Member, Lapis de Tsanfleuron, Early Priabonian. a, c, g: Thin-section SP 139 D-2; b, d, h-i: thin-section SP 139-1; e thin-section SP 139. Scale bars $0.5 \mathrm{~mm}$

transverse view (Fig. 1f). Due to the distally uncalcified laterals and open pores, the axial cavity mostly accounts for more than the preserved outer whorl diameter $(\mathrm{d} / \mathrm{D}$ mean: 0.67). The laterals widen only moderately 

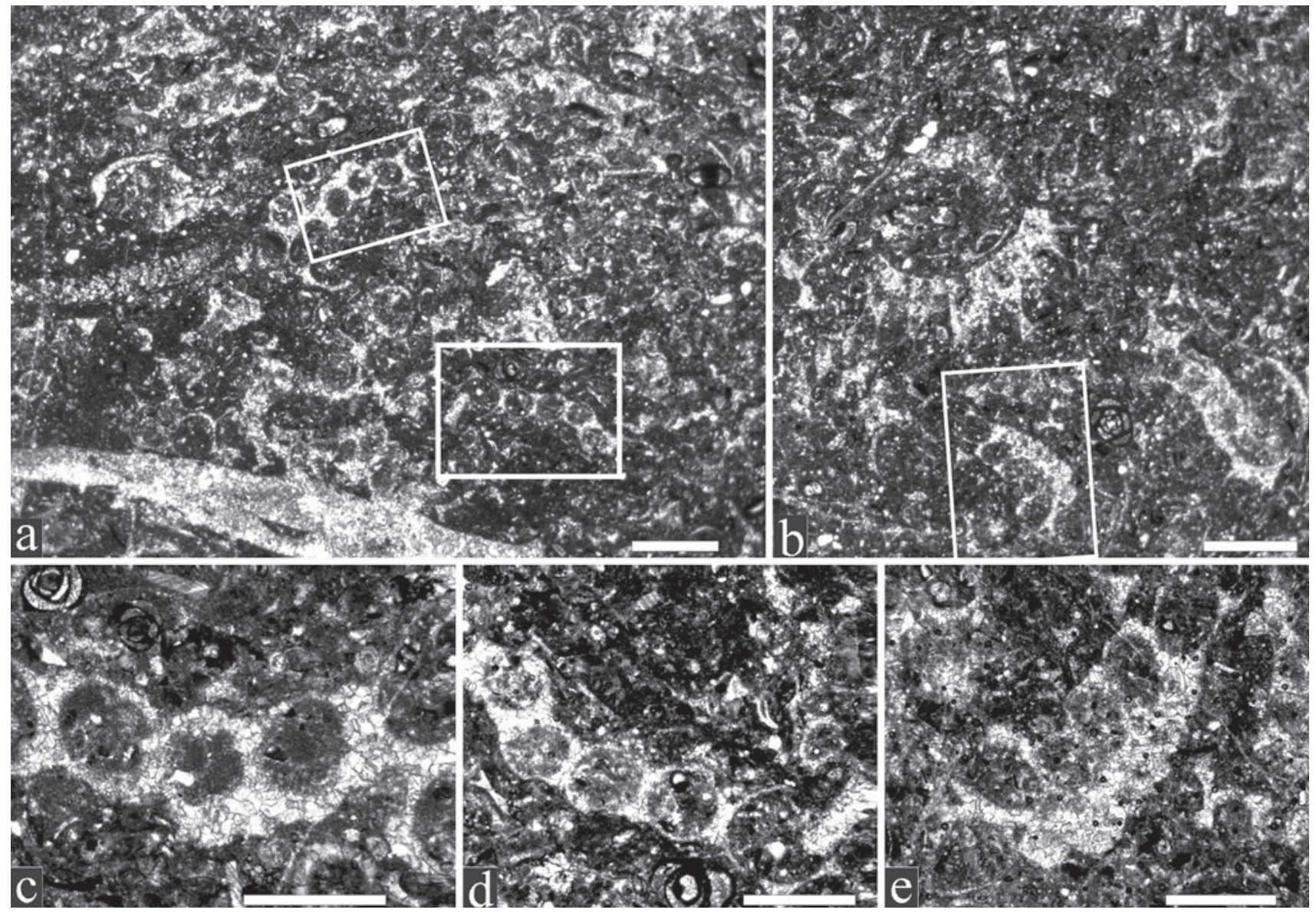

Fig. 8 a-b Wackestone with abundant Clypeina helvetica Morellet and Morellet exhibiting recrystallized whorls made up of sparry calcite (white rectangles mark the details shown in c-e). cd Transverse sections of laterals with subspherical pores. e Subvertical

throughout the length (phloiophorous type) or remain more or less constant in width (akrophorous type). Their diameter ranges from $\sim 0.12$ to $\sim 0.35 \mathrm{~mm}$. Depending on the plane of the section, the transverse sections of the laterals maybe rounded to ovoid (Fig. 7c, e, i). Sections through the bent parts display elongated-ovoid morphologies with the pore opening situated at the upper part, as if the laterals would be compressed perpendicularly to the plane of the whorl (Figs. 1a, 7f, g). Two different calcification patterns of the whorls can be distinguished referring to the assumed original and to a transformed recrystallized type (Figs. 7, 8). The assumed original calcification is composed of a thin outer membrane (thickness $\sim 10$ to $20 \mu \mathrm{m}$ ) enveloping each lateral individually (Fig. 7). This membrane appears either slightly brownish and microgranular, or it is composed of tiny, parallel radially arranged crystal fibers. The boundary between the outer membrane and the inner zone is marked by a thin micritic layer (thickness about $2 \mu \mathrm{m}$ ). The inner zone is made up of hyaline fibrous calcite (thickness $\sim 0.12$ to $0.35 \mathrm{~mm}$ ). The central part may be filled with the micritic matrix (Fig. 7f, i) or completely by section of a whorl proximal to the main stem. Diablerets Member, Lapis de Tsanfleuron, Early Priabonian. Thin-section LT 03. Scale bars $1 \mathrm{~mm}$ for a, b, $0.5 \mathrm{~mm}$ for $\mathrm{c}$, e

cement, locally completely enveloping infiltrated bioclasts (Fig. 7e). Reproductive structures have not been observed inside the laterals. The second type of calcification is represented by uniform and colorless sparry calcite (Fig. 8). Both types, however, have never been observed to occur together within the same sample.

Dimensions

See Table 1.

Remarks

Taking into account our new data, it can be stated that the species description of Morellet and Morellet (1918) based on dispersed verticils on a weathered rock sample (Fig. 5a, b) was very accurate. The new findings from the type area add biometric data and characteristics of the wall structure, allowing further and better comparisons to other Clypeina species. Different calcification patterns of fossil dasycladalean algae were summarized by Conrad and Varol 
Table 1 Dimensions of Clypeina helvetica Morellet and Morellet (in $\mathrm{mm}$, except for the $\mathrm{d} / \mathrm{D}$ ratio)

\begin{tabular}{|c|c|c|c|c|}
\hline & $D$ & $d$ & $\mathrm{~d} / \mathrm{D}$ & $w$ \\
\hline 1 & 1.78 & 0.84 & 0.47 & \\
\hline 2 & 1.92 & 1.32 & 0.68 & \\
\hline 3 & 2.3 & 1.6 & 0.69 & 26 \\
\hline 4 & 1.97 & 1.32 & 0.67 & 28 \\
\hline 5 & 2.2 & 1.52 & 0.69 & \\
\hline 6 & 2.4 & 1.52 & 0.63 & \\
\hline 7 & 2.3 & 1.62 & 0.7 & 30 \\
\hline 8 & 1.6 & 1.01 & 0.63 & \\
\hline 9 & 2.2 & 1.37 & 0.62 & \\
\hline 10 & 1.92 & 1.56 & 0.81 & \\
\hline 11 & 2.43 & 1.5 & 0.78 & \\
\hline 12 & 1.32 & 0.87 & 0.66 & \\
\hline 13 & 2.53 & 1.42 & 0.56 & 26 \\
\hline 14 & 1.72 & 1.01 & 0.59 & \\
\hline 15 & 2.12 & 1.32 & 0.62 & \\
\hline 16 & 2.02 & 1.22 & 0.6 & \\
\hline 17 & 1.7 & 1.17 & 0.69 & \\
\hline 18 & 2.63 & 1.92 & 0.73 & \\
\hline 19 & 2.53 & 1.52 & 0.6 & 32 \\
\hline 20 & 1.72 & 1.14 & 0.66 & \\
\hline 21 & 2.63 & 1.62 & 0.61 & \\
\hline 22 & 1.92 & 1.1 & 0.57 & \\
\hline 23 & 2.63 & 1.52 & 0.58 & \\
\hline 24 & 1.82 & 1.11 & 0.61 & \\
\hline 25 & 1.92 & 1.36 & 0.71 & \\
\hline 26 & 1.72 & 1.09 & 0.63 & \\
\hline 27 & 1.52 & 0.96 & 0.63 & \\
\hline 28 & 2.53 & 1.52 & 0.6 & \\
\hline 29 & 2.53 & 1.36 & 0.53 & \\
\hline 30 & 1.72 & 1.01 & 0.59 & \\
\hline 31 & 1.32 & 0.9 & 0.68 & \\
\hline 32 & 1.7 & 1.02 & 0.6 & 2 \\
\hline 33 & 2.46 & 1.45 & 0.59 & 2 \\
\hline 34 & 2.3 & 1.4 & 0.61 & 22 \\
\hline $\min$. & 1.32 & 0.84 & 0.47 & 2 \\
\hline $\max$ & 2.63 & 1.92 & 0.78 & 32 \\
\hline Mean & 2.05 & 1.31 & 0.64 & \\
\hline
\end{tabular}

$D$ outer diameter of calcified part of the whorl; $d$ inner diameter of whorl; $w$ number of laterals per whorl

(1990). Accordingly, the type evidenced for C. helvetica belongs to the group with "hyaline sheaths, possibly of intracellular origin". It consists of a thin external microcrystalline layer representing the organic membrane and a comparably thick inner layer of hyaline (occasionally yellowish) radial-fibrous calcite of supposed intracellular origin. Each lateral is thereby surrounded by individual sheaths (see De Castro 1997, p. 161, for further details).
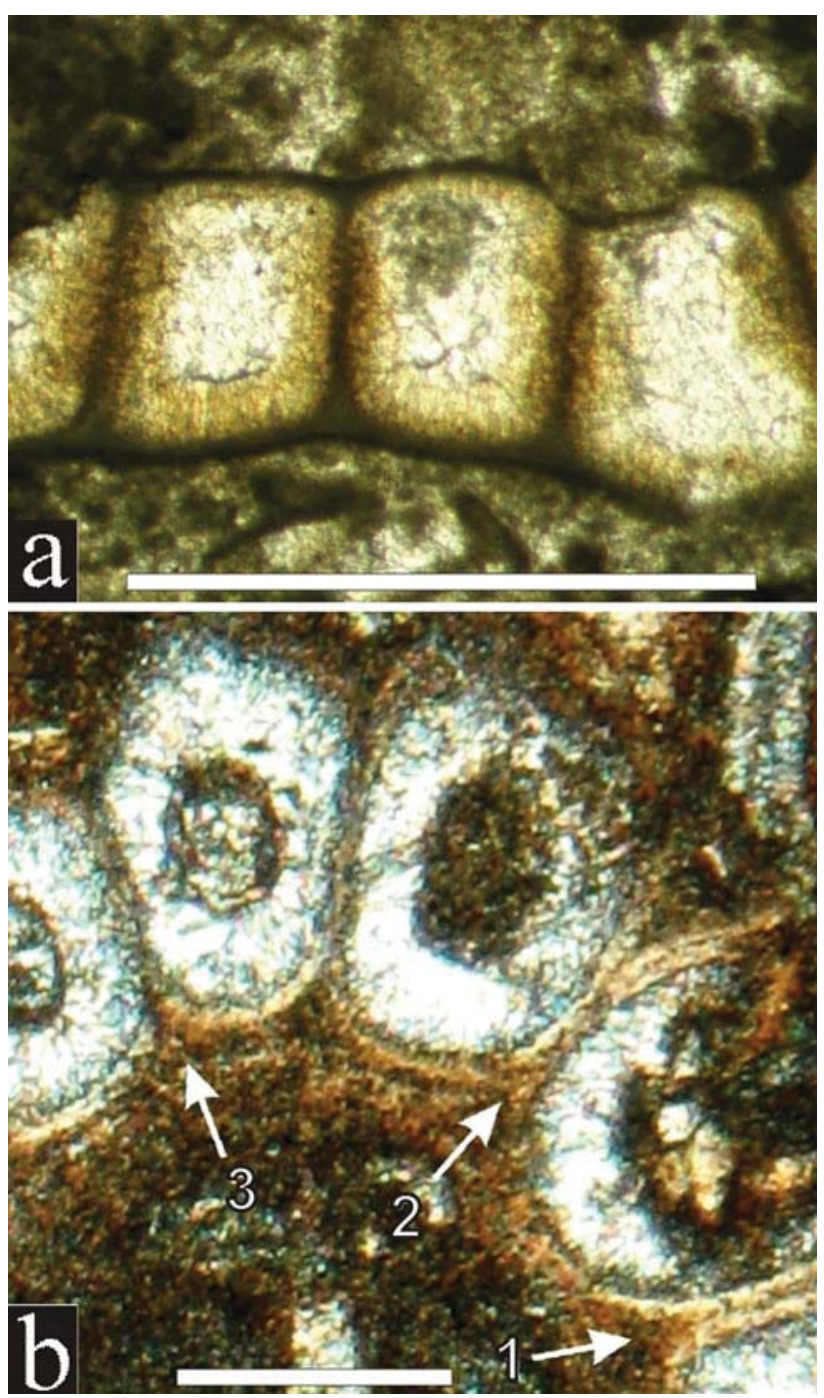

Fig. 9 Examples of the calcification pattern of the "Clypeina jurassica group". a C. jurassica Favre, Kimmeridgian of Albania. b C.? teakolarae Radoičić, Jurkovšek and Jovanović, Early Eocene (Cuisian) of Slovenia. Lateral wall well individualized (arrow 1, 3) to slightly fused (arrow 2) (leg R. Radoičić). Scale bars $1 \mathrm{~mm}$

Examples of this group of species are the Late Kimmeridgian to Late Berriasian Clypeina jurassica Favre (Fig. 9a), the Late Berriasian Clypeina isabellae Masse, Bucur, Virgone, and Delmasso, or the Early Eocene Clypeina teakolarae Radoičić, Jurkovšek and Jovanović (Fig. 9b). Given that Clypeina jurassica is the most widespread and well-known species of all these, Radoičić et al. (2011) referred to them to as the "Clypeina jurassica group". With respect to these examples, one could get the impression that this calcification pattern is restricted to the genus Clypeina, which is not the case. Clypeina? teakolarae, for instance, exhibits spaced double verticils (= twin whorls sensu Radoičić et al. 2011), which are incompatible with the spaced single whorls displayed by Clypeina (e.g., Génot 2009, fig. 2). Depending on the connection of the 

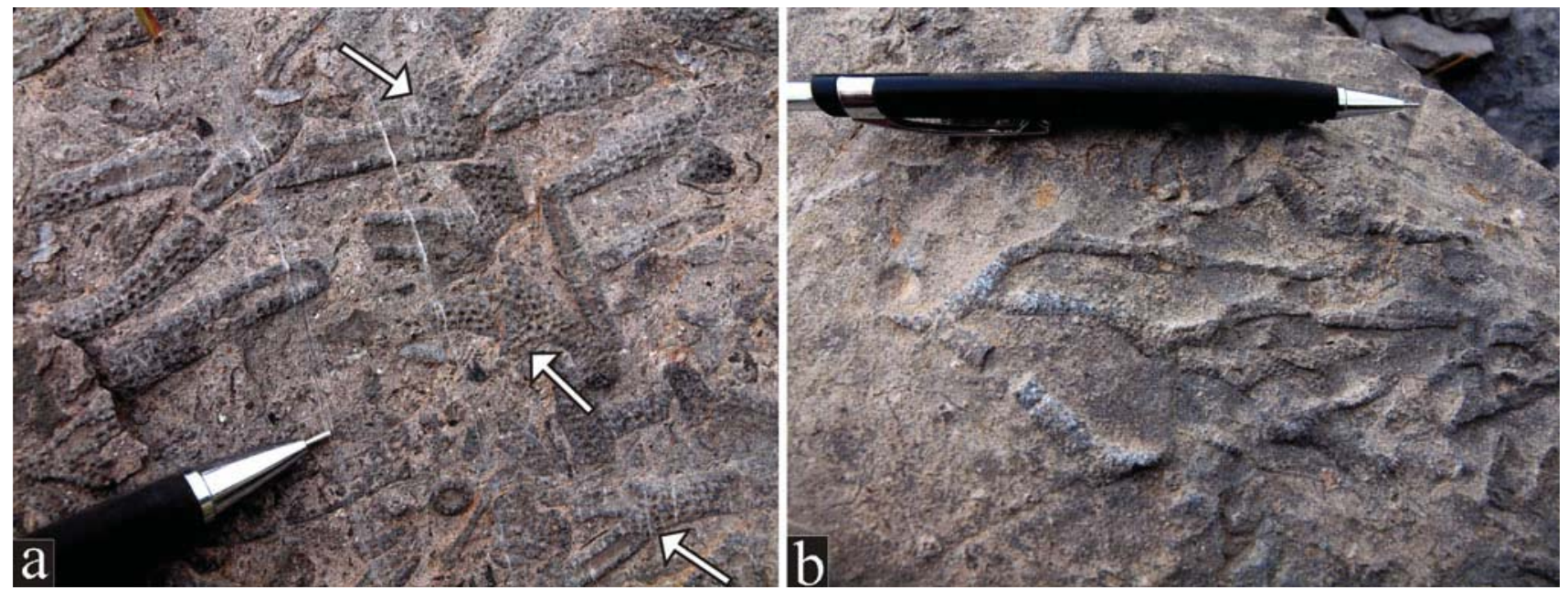

Fig. 10 a Monospecific assemblage of an unknown branching (arrows) dasycladalean alga. b Tree-like branching of unknown dasycladalean alga (from Bover-Arnal et al. 2011, fig. 13d). Diablerets Member, Lapis de Tsanfleuron, Early Priabonian

laterals to the main axis, it should be transferred to Milanovicella Granier and Berthou or Praturlonella Barattolo (see Granier and Berthou 1994 for details). The mentioned taxa also have in common that the laterals are open at their tips. According to Conrad and Varol (1990, p. 206), this feature suggests an in vivo intracellular mineralization process following the release of fertile ampullae. In exceptional cases, the fertile ampullae are preserved enclosed in this intracellular calcification as evidenced from e.g., C. jurassica and C. isabellae (Schlagintweit et al. 2009). Some of the dasycladaleans exhibiting this calcification type were adapted to brackish or polyhaline habitats (Conrad and Varol 1990), an observation that can be ascertained also for the Diablerets Member with Clypeina helvetica. Concerning the two documented types of preservation, the homogeneous sparry calcite undoubtedly results from the transformation of the radial fibrous type. The sparry calcite type usually results from the dissolution of the former aragonite, the mineral that makes up the skeleton of extant Dasycladales (e.g., Berger and Kaever 1992), and the infilling of the mould with calcite cement. Obviously, the two rock samples we studied underwent different diagenetic pathways, with details so far poorly understood. De Castro (1997, pl. 2) illustrated several states of preservation in Clypeina jurassica. Diagenesis can lead to variable infillings of the pores by cement or in an advanced stage to a "crystalline mosaic that uniformly fill(s) the area occupied by both the pores and the associated individual sheats". This recrystallization pattern resembles that of the dissolution of a primary aragonitic skeleton. In summary, $C$. helvetica represents the so far youngest record of a dasycladalean species with this peculiar type of radial-fibrous preservation (see also Granier 2012). Unfortunately, an approach to the problem using modern counterparts is not possible given that the last appearance of the genus Clypeina is in the Early Oligocene (Rupelian) (Barattolo 2002).

Besides $C$. helvetica, there are some other species of dasycladales occurring in the Diablerets Member typically forming monospecific assemblages (Fig. 10). Mass occurrences of individual species indicate that the paleoenvironmental setting was obviously structured and exhibiting several microhabitats (Bover-Arnal et al. 2011). The nowconfirmed Early Priabonian age of the type level of C. helvetica (Menkveld-Gfeller 1994) and the additional findings of other, so far not described, dasycladalean taxa provide further information about the Eocene decline of dasycladaleans. According to Barattolo (2002), 30 species in the Barthonian contrast with only eight species in the Priabonian. The generic extinction, however, reached a relative maximum in the Bartonian, so that-according to Barattolo (2002) — a new period of crisis took place triggered by so far unknown reasons. A refining of the database will be possible by a future thorough systematic study and inventory of the dasycladaleans from the Diablerets Member.

\section{Comparisons}

Morellet and Morellet (1918) compared C. helvetica with the two allied species, $C$. digitata (Parker and Jones) from the Lutetian of France and C. marginiporella Michelin (type species; from the Rupelian of France), both known only as isolated whorls (see also Génot 2009; Génot and Granier 2011). Above all, C. helvetica differs from these two species by its distinctly larger whorls bearing a large number of laterals (Fig. 11). In addition to the biometric data, there are also some differences of the morphology of 


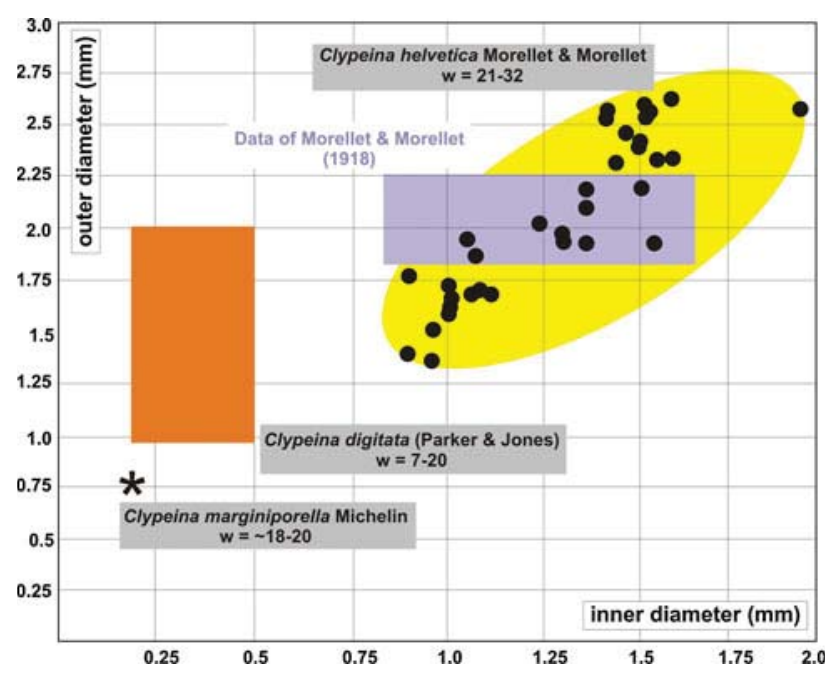

Fig. 11 Outer diameter of calcified part of the whorl (D) against inner diameter (d) (in $\mathrm{mm}$ ) of Clypeina helvetica Morellet and Morellet compared with some other Paleogene Clypeina species that are only known from their isolated whorls: Clypeina marginiporella Michelin (type species; Rupelian of France) and Clypeina digitata (Parker and Jones) (Lutetian of France). Data used are from Deloffre and Génot (1982). The data sets of $C$. digitata and C. helvetica (from Morellet and Morellet 1918) are represented by rectangles as only ranges of both parameters (d, D) were given in the original description. $w$ number of laterals per whorl

the whorls (or umbels in Morellet and Morellet 1918). For C. helvetica, "these are less flat than those of $C$. digitata, but also less infundibuliform than those of $C$. marginiporella" (Morellet and Morellet 1918). Concerning the calcification pattern documented for C. helvetica, it is not known whether it is similar to the one in the other two species.

\section{Stratigraphic distribution}

In the original work of Morellet and Morellet (1918), the age was indicated as "Bartonian à facies littoral (fide Boussac)". This statement most probably refers to Boussac (1912), who worked on the Eocene sediments of the Diablerets region. It should be mentioned that in previous times the Bartonian was considered a superstage comprising the whole Late Eocene. The tripartite subdivision of the Bartonian (Early, Middle, and Late) was, for example, used by Deloffre and Génot (1982) for their stratigraphic range charts of Paleogene Dasycladales, placing C. helvetica within the whole Bartonian up to the Eocene/Oligocene boundary. In the Paleogene standard scale (e.g., Cavelier and Pomerol 1976), the Bartonian is placed between the Lutetian (both Middle Eocene) and the Priabonian (=Late Eocene). According to Menkveld-Gfeller (1994), the Diablerets Member containing Clypeina helvetica is Early Priabonian in age based on nummulitid foraminifera encountered in the Pierredar Member. Therefore, the so-far-assumed occurrence in the Bartonian (see range chart in Barattolo 2002) must be revised. Due to the supposed facies sensitivity of $C$. helvetica, it is unlikely that it occurs in the deeper-water facies types (e.g., nummulitid limestones) that overlie the Diablerets Member. Consequently, it can be assumed that in the type-area, $C$. helvetica is restricted to the Early Priabonian shallow-lagoonal facies.

\section{Conclusions}

Clypeina helvetica is a valid species. So far its occurrence is restricted to the Early Priabonian Diablerets Member of the Sanetsch Formation, which crops out in the Lapis de Tsanfleuron (Diablerets Nappe; western Swiss Alps). In other areas of the Diablerets Nappe, or in other localities in southwestern Switzerland (e.g., Morcles Nappe) and in France (e.g., Chaînes Subalpines) where the Diablerets Member is exposed, the possible occurrence of Clypeina helvetica has to be checked. The documentation of this Dasycladale is of significance in that it provides a data set of a poorly known species, which flourished in a time interval marked by a reduced Dasycladaceae taxonomic diversity with only eight species documented so far.

Acknowledgments Robin Marchant (Geological Museum of Lausanne) kindly provided photographs of and information on the original material of Clypeina helvetica. David Jaramillo-Vogel is thanked for his help with the sampling. Financial support for the research was provided by the Swiss National Science Foundation grants no. 20-121545 and 20-137568 to TBA and AS. Many thanks to the reviewers Filippo Barattolo (Naples) and Marc Conrad (Perly) for their helpful comments on the manuscript.

\section{References}

Barattolo F (2002) Late Cretaceous-Paleogene dasycladaleans and the K/T boundary problem. In: Bucur II, Filipescu S (eds) Research advances in calcareous algae and microbial carbonates. Cluj University Press, Cluj, pp 17-40

Berger S, Kaever MJ (1992) Dasycladales: an illustrated monograph of a fascinating algal order. Thieme, Stuttgart, $247 \mathrm{pp}$

Bover-Arnal T, Jaramillo-Vogel D, Showani A, Strasser A (2011) Late Eocene transgressive sedimentation in the western Swiss Alps: records of autochthonous and quasi-autochthonous biofacies on a karstic rocky shore. Palaeogeogr Palaeoclimatol Palaeoecol 312:24-39

Boussac J (1912) Étude stratigraphique sur le Nummulitique Alpin. Mém Carte Géol France

Cavelier C, Pomerol Ch (1976) Les rapports entre le Bartonien et le Priabonien. Incidence sur la position de la limité Eocène moyenEocène superieur. C R somm Soc géol Fr 2:49-51

Conrad MA, Varol B (1990) Cylindroporella taurica, n. sp., urges to review different patterns of calcification in the Mesozoic Dasycladales (Green Algae). Arch Sci Genève 43:193-214

De Castro P (1997) Introduzione allo studio in sezione sottile delle Dasicladali fossili (An approach to thin-section study of fossil Dasycladales). Quad accad pontaniana 22:1-26 
Deloffre R, Génot P (1982) Les Algues Dasycladales du Cénozoïque. Bull Cent Rech Explor-Prod Elf-Aquitaine Mém 4:1-247

Génot P (2009) Cenozoic Dasycladales. A photo-atlas of Lutetian species from French Cenozoic basins. Carnets Géol - Notebooks Geol Spec Publ 2009/001. CG2009_SP01

Génot P, Granier B (2011) Cenozoic Dasycladales. A photo-atlas of Thanetian, Ypresian and Bartonian species from the Paris Basin. Carnets Géol: Notebooks Geol CG2011_SP01

Granier B (2012) The contribution of calcareous green algae to the production of limestones: a review. Geodiversitas 34:35-60

Granier B, Berthou PY (1994) Déscription de Milanovicella momciliana n. gen., n. sp., algue dasycladale du Portlandien de l'Algarve Central (Portugal), et validation de quelques taxons affins. Rev Micropaléont 37:113-121

Herb R (1988) Eocäne Paläogeographie und Paläotektonik des Helvetikums. Eclogae Geol Helv 81:611-657

Linder P (2005) An Eocene paleodoline in the Morcles Nappe of Anzeindaz (Canton of Vaud, Switzerland). Eclogae Geol Helv 98:51-61

McNeill J, Barrie FR, Demoulin V, Hawksworth DL, Wiersema JH (2006) International Code of Botanical Nomenclature (Vienna Code). 17th Int Bot Congr Vienna Austria July 2005, Regnum Vegetabile 146. A.R.G. Gantner Press, Vienna

Menkveld-Gfeller U (1993) Stratigraphie und Paläogeographie des Eocaens der helvetischen Decken der Westschweiz
(Diablerets- und Wildhorn-Decke). Unpubl. PhD Thesis, University of Bern, $105 \mathrm{pp}$

Menkveld-Gfeller U (1994) Die Wildstrubel-, die Hohgant- und die Sanetsch-Formation: Drei neue lithostratigraphische Einheiten des Eocaens der Helvetischen Decken. Eclogae Geol Helv 87:789-809

Menkveld-Gfeller U (1995) Stratigraphie, Fazies und Palaeogeographie des Eocaens der helvetischen Decken. Eclogae Geol Helv 88:115-134

Morellet L, Morellet J (1918) Observations sur le genre Clypeina Michelin. Bull Soc Géol Fr 4º ser 18:102-105

Radoičić R, Jurkovšek B, Jovanović D (2011) Clypeina teakolarae sp. nov., a dasycladalean alga from Lower Eocene of Rakitovec (Čičarija, Slovenia). Geologija 54:13-30

Schlagintweit F, Dieni I, Radoičić R (2009) Two look-alike dasycladalean algae: Clypeina isabellae Masse, Bucur, Virgone \& Delmasso, 1999 from the Berriasian of Sardinia (Italy) and Clypeina loferensis sp. n. from the Upper Jurassic of the Northern Calcareous Alps (Austria). Ann Géol Pénins Balk 70:43-59

Weidmann M, Franzen J, Berger JP (1991) Sur l'âge des couches à Cérithes ou couches des Diablerets de $1^{\prime}$ Eocène alpin. Eclogae Geol Helv 84:893-919 